\title{
Upgrading Keterampilan Jurnalistik dan Literasi Media sebagai Media Exposed Potensi Desa Melalui Pengelolaan Website
}

\author{
Muhammad Hanif Fahmi ${ }^{1}$, Sri Widayati ${ }^{2}$, Lian Agustina Setiyaningsih ${ }^{2}$ \\ ${ }^{1}$ Program Studi Sistem Informasi Universitas Islam Raden Rahmat Malang, Jalan Raya Mojosari No. 2 , \\ Kepanjen, Malang, Indonesia 65163 \\ ${ }^{2}$ Program Studi Ilmu Komunikasi Universitas Merdeka Malang, Jalan Terusan Dieng No.62-64, Malang, \\ Indonesia 65146
}

Correspondence: Lian Agustina Setiyaningsih (lian.agustina@unmer.ac.id)

Received: 30 Juni 2021 - Revised: 01 Agustus 2021 - Accepted: 16 Agustus 2021

\begin{abstract}
Abstrak. Perkembangan teknologi mempengaruhi segala sektor kehidupan, akselerasi penggunaan media berbasis teknologi berdampak pada literasi masyarakat. Masyarakat di pedesaan rentan terhadap iliterasi media. Hal ini merupakan pintu masuk sebuah pemberdayaan masyarakat desa untuk menjadi melek media dan mampu menjadi pengguna media teknologi yang cerdas. Desa harus beradaptasi dengan kemajuan teknologi terutama dalam hal pemanfaatan potensi desa. Karang taruna dan petinggi desa Sitiarjo di Kabpaten Malang belum memiliki kemampuan juralistik dan kemampuan literasi media untuk menyokong pengelolaan web desa. Permasalahan mitra adalah 1) perangkat desa belum memliki kemampuan jurnalistik untuk mengelola website desa. 2) karang taruna tidak memiliki kemampuan literasi media dan jurnalistik untuk membangun kebiasanaan sehat dalam bermedia. Sehingga untuk merespon permasalahan tersebut, dapat dilakukan adalah memberikan keterampilan jurnalistik dan literasi media pada perangkat desa dan karang taruna desa Sitiarjo. Kegiatan ini merupakan pintu masuk untuk menciptakan ekosistem sehat dalam bermedia. Melalui metode pelatihan dan simulasi Iptek kegiatan ini menghasilkan kemampuan membuat konten web dan keterampilan literasi media oleh perangkat desa dan karang taruna desa Sitiarjo. Kedua keterampilan tersebut digunakan untuk pengelolaan web desa yang output akhirnya adalah media expose eksplorasi dan publikasi potensi desa.
\end{abstract}

Kata kunci: Jurnalistik, Literasi Media, Media Expose, Web Desa.

Citation Format: Fahmi, M.H., Widayati, S., \& Setiyaningsih, L.A. (2021). Upgrading Keterampilan Jurnalistik dan Literasi Media sebagai Media Exposed Potensi Desa Melalui Pengelolaan Website. Prosiding Seminar Nasional Abdimas Ma Chung (SENAM), 266-279. 


\section{PENDAHULUAN}

Percepatan perkembangan teknologi informasi membuat kebingungan dan kegaduhan dalam pemahaman terhadap informasi. Perubahan besar terjadi di pedesaan, dimana masyaraat desa mengalami kesenjangan dan detreminasi teknologi hingga kesenjangan sosial (Mishori, \& Antono, 2020; Oktavianoor, 2020; Song et al., 2020). Di sisi lain, keberlimpahan informasi di media yang berbasis teknologi menjadi tantangan tersendiri bagi masyarakat desa. Kebutuhan masyarakat akan informasi dibarengi dengan keberadaan teknologi menjadikan ruang lingkup lebih sempit karena sesak dengan kelimpahan informasi (Gui, \& Büchi, 2021; Hertati et al., 2020). Media yang mengungkapkan Sistem Informasi Desa (SID) sangat diperlukan dalam membangun citra desa. alam membangun sebuah citra dan persepsi positif perlu cara pandang yang dihadirkan melalui media. Dengan cara pandang itu publik akan menentukan pilihannya. Mengenai informasi yang dipublikasikan melalui website akan membentuk persepsi atau citra tentang desa.

Website desa merupakan salah satu media yang daapat digunakan untuk mengatasi kesenjangan, determinasi teknologi masyarakat di pedesaan selain itu, pemanfaatan media tersebut juga memiliki keuntungan untuk melakukan promosi atas potensi desa, Pemanfaatan Teknologi Informasi dan Komunikasi (TIK) merupakan salah satu solusi dalam mewujudkan keadilan bagi seluruh masyarakat Indonesia untuk mendapatkan informasi mengenai isu-isu pemerintahan dan pelayanan publik yang optimal sampai tingkat pedesaan. Keberadaan website desa menjadi fenomena baru dalam komunikasi pembangunan pedesaan, sehingga perlu diketahui sejauh mana efektivitasnya. Tujuan pengabdian ini melakukan pemberdayaan dengan peninggkatan keterampilan jurnalistik dan literasi media kepada perangkat desa dan karang taruna. Alasan kedua kelompok dilibatkan dalam pemberdayaan karena keduanya merupakan filter atau gatekeeper informasi tertiggi di tingkatan desa.

Perangkat desa dan karang taruna di desa SItiarjo merupakan gatekeeper dan filter atas informasi yang berkembang di daerah tersebut. Sehingga mereka merupakan pusat informasi dan memiliki kewajiban untuk mendidik dan memberdayakan masyarakat lain terutama yang berkaitan dengan perkembangan teknologi. Hal ini dikarenakan sebagian 
besar masyarakat Sitiarjo belum memiliki keterampilan literasi media. Sehingga mudah sekali terkena hoax dan mudah melakukan tindakan yang sifatnya illiterasi media.

Distribusi percepatan teknologi terlihat tidak merata, sebab jika melihat di daerah perkotaan penggunaan media sudah banyak diiringi dengan literasi media. Namun di desa pesisir hal ini belum menjadi kebiasaan bahkan budaya dalam keseharian masyarakatnya. Oleh karenanya keberadaan karang taruna yang melek media mampu menmberikan pendidikan dalam menggunakan media berbasis teknologi dan meminimalisir kriminalisasi atas penggunaan media sosial.
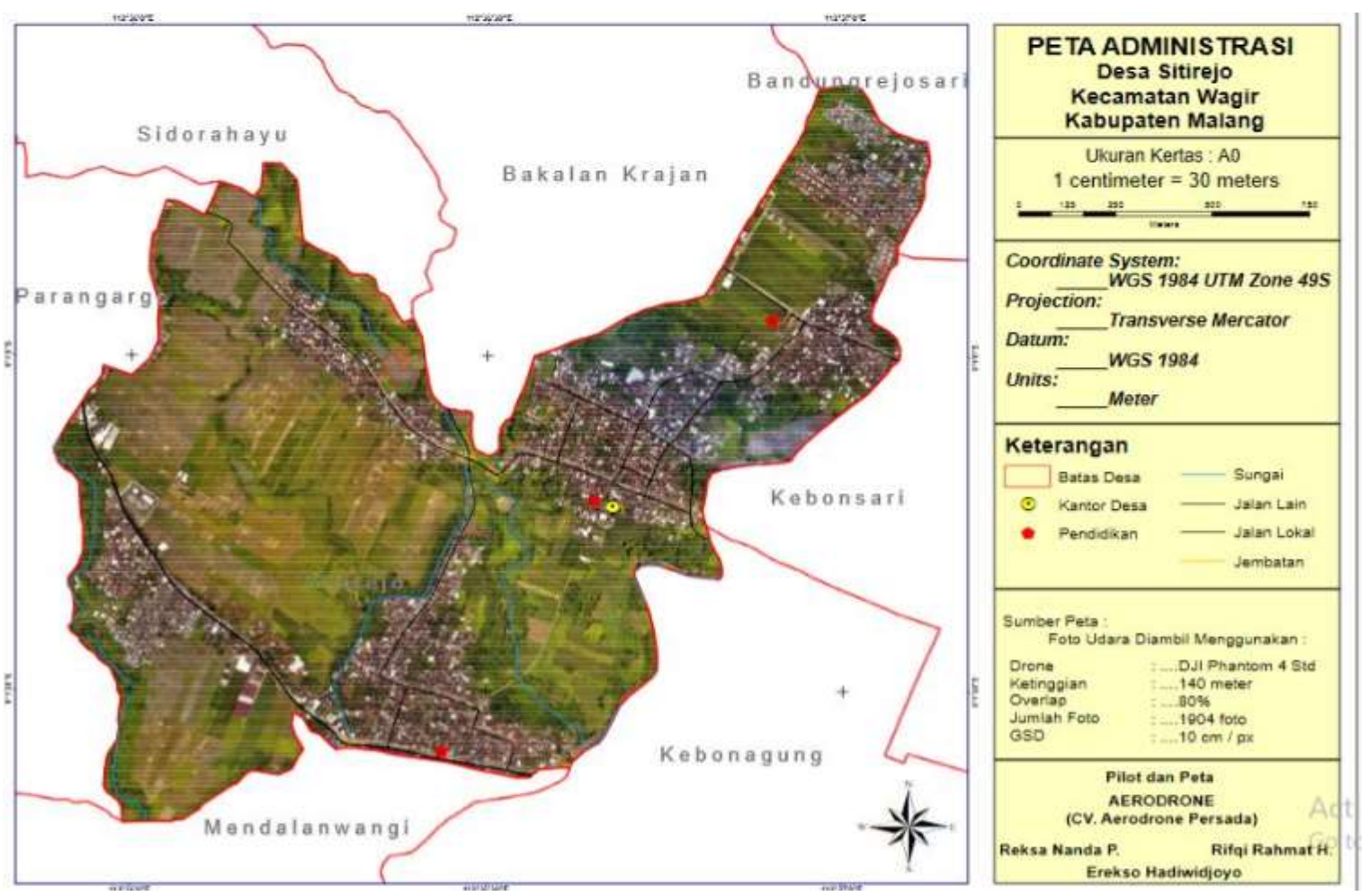

Gambar 1. Peta Desa Sitiarjo (BPS, 2019)

Secara geografis Desa Sitirejo terletak pada posisi $7^{\circ} 96^{\prime}-7^{\circ} 02^{\prime}$ Lintang Selatan dan $111^{\circ} 31^{\prime}-112^{\circ} 61^{\prime}$ Bujur Timur. Topografi ketinggian desa ini adalah berupa daratan sedang yaitu sekitar $413 \mathrm{~m}$ di atas permukaan air laut. Berdasarkan data BPS kabupaten Malang tahun 2010, selama tahun 2010 curah hujan di Desa Sitirejo rata-rata mencapai $2.400 \mathrm{~mm}$. Curah hujan terbanyak terjadi pada bulan September hingga mencapai 405,04 mm yang merupakan curah hujan tertinggi selama kurun waktu 2009 - 2010. 
Secara administratif, Desa Sitirejo terletak di wilayah Kecamatan Wagir Kabupaten Malang dengan posisi dibatasi oleh wilayah desa-desa tetangga. Di sebelah Utara berbatasan dengan Kelurahan Kebonsari Kecamatan Sukun Kota Malang. Di sebelah Barat berbatasan dengan Desa Parangargo Kecamatan Wagir. Di sisi Selatan berbatasan dengan Desa Mendalanwangi Kecamatan Wagir, sedangkan di sisi timur berbatasan dengan Desa Kebon Agung Kecamatan Pakisaji. Jarak tempuh Desa Sitirejo ke ibu kota kecamatan adalah $3 \mathrm{~km}$, yang dapat ditempuh dengan waktu sekitar 10 menit. Sedangkan jarak tempuh ke ibu kota kabupaten adalah $16 \mathrm{~km}$, yang dapat ditempuh dengan waktu sekitar 30 Menit.

Berdasarkan data Administrasi Pemerintahan Desa tahun 2019, jumlah penduduk Desa Sitirejo adalah 10.175 jiwa, dengan rincian 5.123 laki-laki dan 5.052 perempuan. Jumlah penduduk demikian ini tergabung dalam 2.862 KK. Agar dapat mendeskripsikan dengan lebih lengkap tentang informasi keadaan kependudukan di Desa Sitirejo maka perlu diidentifikasi jumlah penduduk dengan menitikberatkan pada klasifikasi usia. penduduk usia produktif pada usia 20-49 tahun Desa Sitirejo sekitar 5137 Orang atau hampir 50,5\%. Hal ini merupakan modal berharga bagi pengadaan tenaga produktif dan SDM.

Pengelola website dan bertambahnya pengetahuan serta keterampilan tentang teknis penggunaan website, pencarian informasi tentang ilmu pengetahuan dan teknologi membuat menjadi liteasi media (Kurniawan et al., 2021; Yulida et al., 2020). Sedangkan dalam Sani et al., (2020), untuk mengatasi kesenjangan teknologi sendiri membutuhkan pengetahuan serta kemampuan adopsi dan adaptasi. Hal ini menjadikan permulaan untuk karang taruna dan petinggi desa agar mereka menjadi peer education bagi warganya. Penguatan literasi media dilakukan untuk meningkatkan kesadaran agar terhindar dari cyber crime. Penyebaran hoaks dan pencemaran nama baik menjadi hal utama dalam penggunaan media. Sehingga hal ini perlu diajarkan kepada seluruh masyarakat (Herlina \& Husada, 2019).

Pemerintah telah mencanangkan literasi media agar masyarakat terhindar dari jeratan hukum dalam penggunaan media. Peningkatan potensi daerah juga dipengaruhi oleh penggunaan website desa. Sehingga permberdayaan secara kelompok menjadi lebih mudah dilaksanakan untuk mencapai hasil maksimal. Seperti juga yang telah dilakukan 
pada peningkatan hasil tani nanas di Kabupaten Malang. Dimana petani nanas mampu meningkatkan potensi daerahnya melalui pemanfaatan media berbasis teknologi (Setiyaningsih \& Fahmi, 2020). Pada dasarnya kegiatan ini memiliki tujuan untuk membetuk literasi penggunaan media pada masyarakat desa. Kondisi masyarakat desa yang teliterasi akan membantu pemerintah desa Sitiarjo untuk mengembangkan potensi desa dan meningkatkan pendapatan masyarakat desa. Oleh karenanya, keterlibatan karang taruna dan petinggi desa dalam kegiatan ini bermaksud sebagai peer education yang dapat memfasilitasi dan mendidik masyarakat desa Sitiarjo secara keseluruhan. Hasil akhir yang diharapkan adalah terbentuknya kemampuan literasi, kemampuan pengelolaan secara mandiri website desa, serta meningkatnya potensi dan perekonomian desa.

\section{MASALAH}

Permasalahan mitra jika digaris bawahi terletak pada minimnya penguasaan keterapilan jurnalistik dan literasi media. Sedangkan jika melihat kajian di atas, kedua hal tersebut memiliki manfaat sebagai bekal agar tidak terjadi illeterasi media. Hal utama yang dibutuhkan oleh perangkat desa dan karang taruna adalah kemapuan mengelola konten website desa. Tujuannya untuk meningkatkan potensi desa dan membebaskan masyarakat desa dari illiterasi media.

Selama ini, website desa sudah ada dan diberikan oleh pemerintah Kabupaten Malang. Seluruh desa di Kabupaten Malang sudah disediakan domain. Di dalam website desa tersebut juga sudah siap untuk digunakan. Tata letak dan kolom-kolom website sudah disajikan secara sederhana. Namun sejauh ini, desa Sitiarjo tidak memanfaatkan website tersebut. Hingga pada akhirnya karang taruna dan perangkat desa yang sedang mengembangkan potensi wisata mengalami kebuntuan untuk melakukan promosi wisata. Dan hal tersebut menjadi permaslahan pertama di desa Sitiarjo.

Permasalahan kedua terletak pada masyarakat desa Sitiarjo yang tergolong dalam kelompok technology devide dan technology determination. Penggunaan media sosial dan kelimpahan informasi yang dikondiakses setiap hari menjadikan kesalahan pemahan atas informasi yang didapat. Seperti misalnya banyak yang mempercayai hoax, menyebarkan informasi tanpa melakukan konfirmasi dan mudah percaya dengan berbagai informasi yang bertebaran di media sosial. Hal tersebut terindikasi sebagai kelompok masyarakat yang belum melek media. Oleh karenanya pemberian keterampilan jurnalistik dan literasi media 
diharapkan mampu dimiliki secara mandiri oleh karang taruna dan petinggi desa, mengingat mereka merupakan pintu masuk informasi di tingkatan desa.

Dari permasalahan yang terdapat di lapang, solusi pemberdayaan yang dapat dirumuskan untuk menyelesaikan maslaha adalah pemetaan kondisi karangtaruna dan petinggi desa Sitiarjo, pemberian keterampilan jurnalistik dan literasi media, serta pengelolaan wesite desa. Target dari kegiatan pelatihan ini adalah terciptanya literasi media terutama media sosial, menghasilkan keterampilan jurnalistik dan pengelolaan konten website desa.

\section{METODE PELAKSANAAN}

Kegiatan ini memiliki dua metode yakni pelatihan dan simulasi Iptek. Metode palatihan dipilih karena kegiatan ini bertujuan untuk mentransformasikan perubahan sikap di desa Sitiarjo. Dalam metode pelatihan di dalamnya terdiri dari kegiatan diskusi pembekalan dan eksplorasi keterampilan karang taruna dan petinggi desa. Pembekalan dan eksplorasi keterampilan jurnalistik dan literasi media terdiri dari dua langkah. Pembekalan ketermapilan jurnalistik dan literasi media kepada petinggi desa dan karang taruna. Untuk menopang kemampuan mereka dalam mengelola website desa dan menjadi kader yang mengajari masyarakat lainnya. Langkah pengembangan keterampilan melalui pengelolaan konten dan pengoperasian website desa.

Sedangkan simulasi Iptek sendiri dilakukan dengan cara pemodelan untuk menjelaskan proses pengelolaan website desa dan kecerdasan masyarakat desa dalam menggunakan media. Adapun simulasi Iptek ini dilakukan dengan tahapan berikut a) mengukur efektifitas website bagi pengelola; b) penetapan pemanfataan website; c) menerapkan keterampilan dalam pengelolaan konten website; d) evaluasi pengelolaan konten website (Mulyawaty et al., 2016).

Pada gambar 2 dibawah ini adalah bagan metode kegiatan pemberdayaan pada perangkat desa dan karang taruna desa Sitiarjo: 


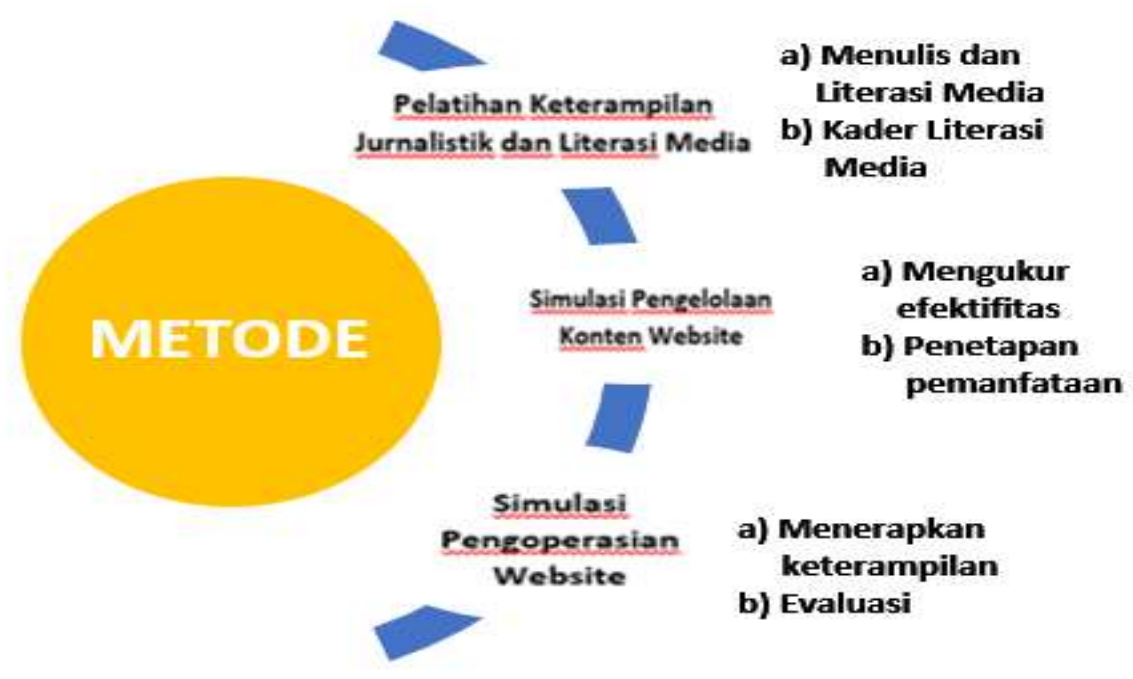

Gambar 2. Metode Pelaksanaan Kegiatan

\section{HASIL DAN PEMBAHASAN}

\section{Upgrading Keterampilan Jurnalistik dan Literasi Media}

Permasalahan keterbatasan infrastruktur saat ini sudah tidak menjadi kendala di desa Sitiarjo. Di desa ini internet terpasang di simpul-simpul daerah yang dapat digunakan secara random oleh warga yang berada di sekitar lokasi tersebut. Permasalahannya adalah terletak pada pemanfaatan internet dan media yang dapat meningkatkan pendapatan desa dan msayarakatnya. Hamper seluruh desa di Kabupaten Malang, saat ini berlomba-lomba melakukan eksplorasi wisata untuk dijadikan sebagai sumber pendapatan desa dan meningkatkan perekonomian masyarakat. Dari hasil kajian Anwar et al., (2020) menyatakan bahwa web desa berfungsi sangat efektif untuk media promosi wisata desa secara transparan. Oleh karenanya, potensi tersebut menjadi sangat penting untuk dikembangkan melalui pengambangan ketrampilan jurnalistik dan literasi media agar pemanfaatan website menjadi lebih efektif.

Literasi media merupakan kemampuan individu dalam berkomunikasi, memetakan dan merangkai dan memahami konten dalam media. Kemampuan literasi media dapat menjadi gambaran kemampuan mitra dalam mengikuti perkembangan teknologi informasi dan komunikasi, terutama kemampuan memanfaatkan media dalam kaitannya mencari dan memanfaatkan informasi. Peran teknologi informasi dan 
komunikasi menggunakan internet diperlukan dalam mendidik masyarakat dan memberikan data yang informatif. Kebutuhan masyarakat untuk mengakses dan berbagi informasi mendatangkan kekhawatiran terjadinya kesalahan dalam pemanfaatan media.

Dalam Nurhayati et al., (2021) kesalahan dalam pemanfaatan media saat ini dapat mendatangkan kejahan di dunia siber (cyber crime). Pembekalan keterampilan jurnalistik dan literasi media dibagi menjadi dua yakni memberikan kemampuan dan ketrampilan menulis dan literasi serta menjadikan mitra sebagai kader yang mendidik masyarakat berkaitan tentang literasi media. Kedua hal ini dilakukan dalam rangka memberikan keterampilan dasar a) melek media, b) menjadi kader untuk mendidik masyarakat lainnya, c) sebagai komunikator yang mampu membuat konten website, d) kemandirian pengelolaan website desa.

Pelatihan jurnalistik dan literasi media diberikan selama dua minggu sekali dalam dua bulan. Sehingga total pelatihan sebanyak empat kali dalam pemberdayaan. Materi yang diberikan saat pelatihan jurnalistik adalah dasar jurnalistik, dasar menulis dan menyajikan data dan berita serta teknik wawancara dan pengumpulan data menggunakan search engine. Sedangkan materi literasi media yang diberikan kepada karang taruna dan petinggi desa antara lain bahaya hoax, penggunaan media sosial serta self healing media sosial. Pelatihan ini dilakukan secara daring dan luring. Pelatihan secara daring dilakukan saat pelatihan literasi media. Gambar berikut merupakan partisipasi karang taruna dan petinggi desa dalam pelatihan jurnalistik dan literasi media.

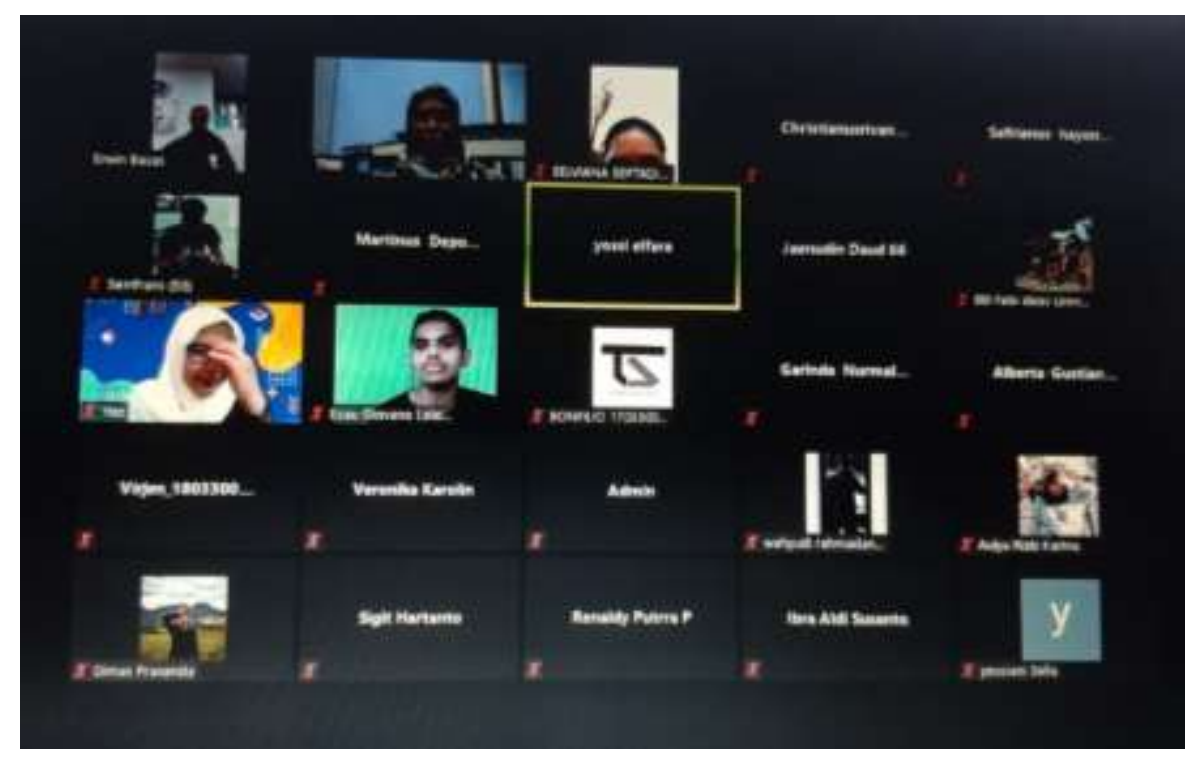

Gambar 3. Pelatihan Daring Jurnalistik dan Literasi Media 
Pelatihan luring dilakukan di balai desa Sitiarjo yang melibatkan karang taruna dan petinggi desa. Keseluruhan peserta melakukan praktek menulis berita terkait potensi desa SItiarjo. Sedangkan dalam pelatihan literasi media, peserta melakukan praktek simulasi menjadi peer education kepada masyakata desa Sitiarjo agar menjadi melek media dalam penggunaan media teknologi terutama media sosial.
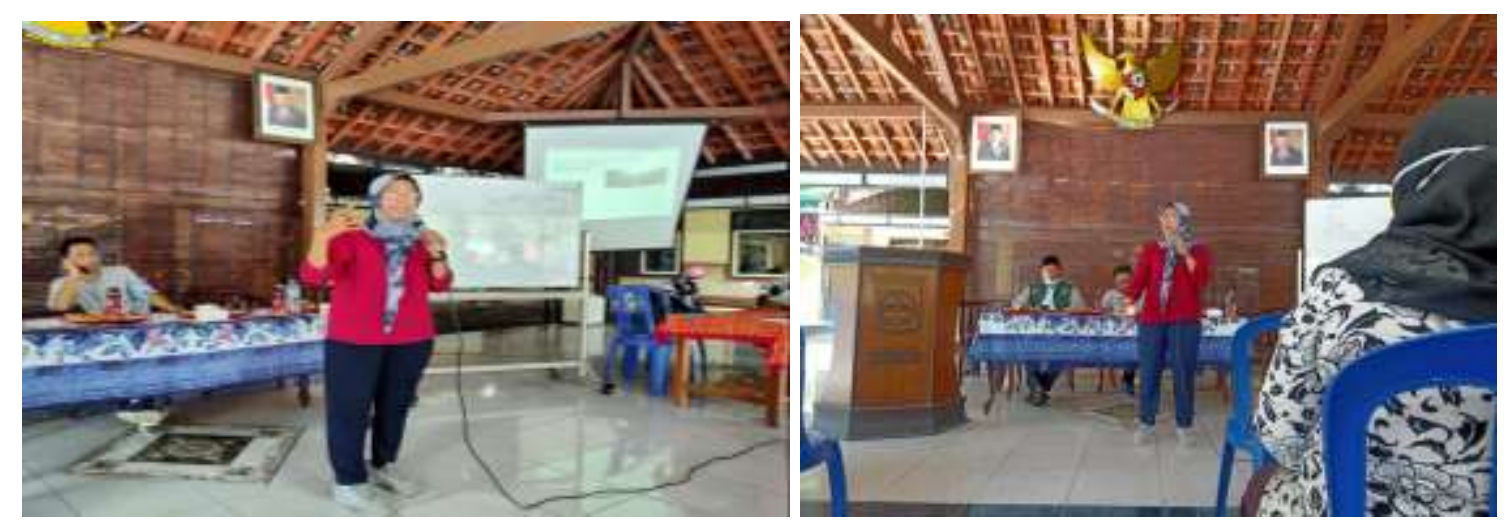

Gambar 4. Pelatihan Jurnalistik dan Literasi Media

Pelatihan ini menggunakan metode partisipasi aktif peserta. Pada awal pelatihan memberikan materi terlebih dahulu kemudaian menyajikannya dalam bentuk prakter secara mandiri. Gunanya adalah agar karang taruna dan petinggi desa memiliki pengalaman mandiri atas keterampilan menulis dan menjadi agen pendidik masyarakat. Proses evaluasi dilakukan pada bulan keempat dan partisipasi aktif mitra memberikan kontribusi besar atas keberhasilan pelatihan.

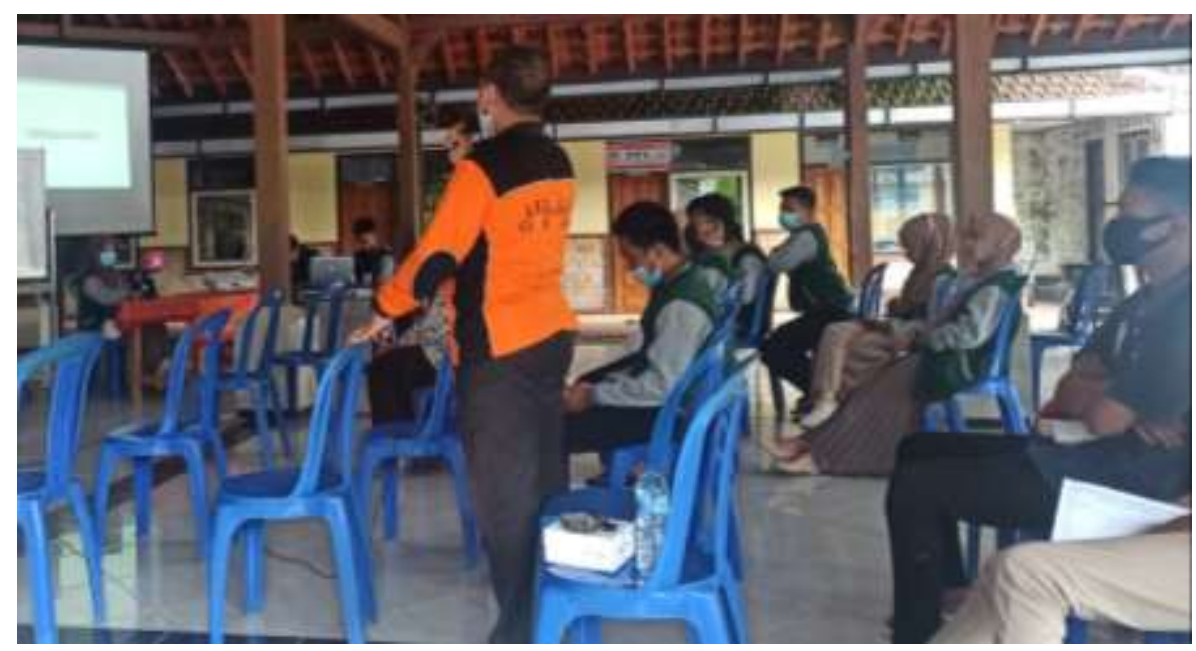

Gambar 5. Evaluasi Penulisan Konten Website Desa 
Pada minggu keempat mitra telah dapat menulis berita singkat mengenai potensi wisata yang ada di desa Sitiarjo dan berhasil menghimpun data melalui serach engine mengenai data kependudukan di Kabupaten Malang. Selain itu mereka juga sudah berhasil melakukan simulasi peer education antar sesama mengenai literasi media. Dalam Marta et al., (2019) tata cara penulisan harus sesuai dengan kaidah penulisan sehingga dapat menyajikan konten secara faktual.

\section{Media Expose Potensi Desa melalui Pembuatan dan Pengelolaan Konten Website Desa}

Kegiatan pembuatan dan pengelolaan konten website desa merupakan langkah tindak lanjut sebagai penguatan keterampilan yang sudah ada. Mitra sebagai peserta pelatihan berlatih membuat konten website desa. Selama ini website desa masih kosong dan belum dioperasikan. Namun setelah pelatihan ini, website desa Sitiarjo berhasil dioperasikan oleh karang taruna dan divisi perhubungan desa untuk pengembangan potensi daerah.

Kendala kegagapan teknologi tidak hanya dialami oleh penduduk desa yang ada di Indonesia. Beberapa negara di Asia melalui berbagai kajian juga mengalami kegagapan teknologi seperti misalnya India masyarakat desanya secara ekstrim takut menggunakan teknologi (Srivastava et al.,2019); penduduk desa di Kamboja mengalami kesulitan adaptasi atas perkembangan teknologi (He, 2019). Negara Cina yang terkenal dengan kecanggihan teknologi, penduduk desanya juga mengalami kebingungan saat menjalankan bisnis yang telah mengadopsi kecanggihan teknologi (Lyu et al., 2019). Sama halnya dengan fenomena di atas, kendala utama yang dialami dalam pelatihan dan simulasi iptek terkait pengelolaan web terletak pada rasa takut salah atau keliru dalam memanfaatan fitur pada web. Sehingga peserta selalu mengalami kendala gagap teknologi saat melakukan simulasi mengelola website. Dalam membuat konten website tidak muncul kendala yang berarti, dengan kata lain, peserta mampu mengenali potensi desa sehingga mampu melakukan pemetaan dengan baik atas desa Sitiarjo. 


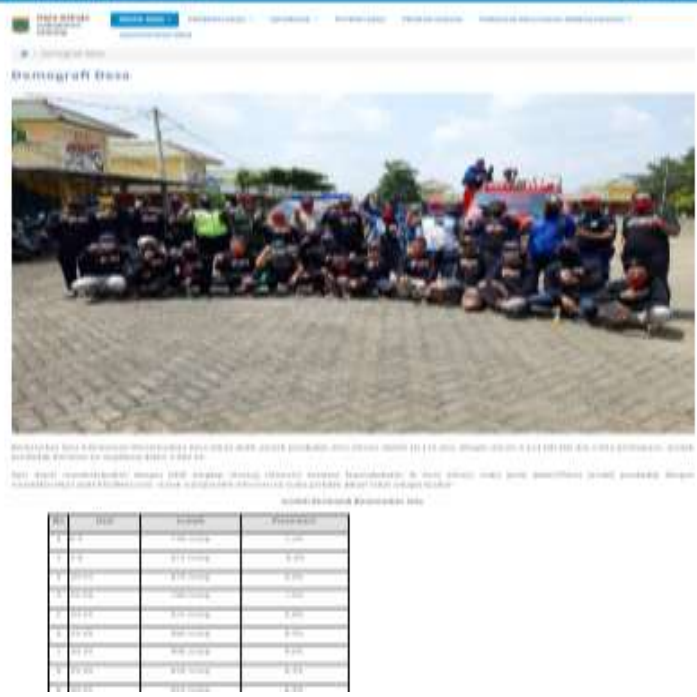

Gambar 6. Pembuatan Konten Profil Demografis Desa

Kegiatan ini juga berlanjut dalam mengisi konten terkait data geografis desa, dimana karang taruna dan divisi humas mampu merangkai konten peta desa dan deskripsi desa. Data yang digunakan berasal dari sumber literature desa yang selama ini hanya berupa arsip tertulis manual saja. Namun melalui website desa ini, mereka mampu mempublikasikannya sehingga hal ini membantu menjadikan desa Sitiarjo sebagai desa melek teknologi. Hal ini merupakan langkah awal media exposed dalam pemanfaatan media berbasis teknologi. Media expose merupakan fungsi media berbasis teknologi dengan menebalkan atau menonjolkan potensi desa sesuai tujuan. Seperti yang pernah dilakukan di China, berhasil melakukan media exposed untuk mengurangi korban gempa bumi di desa yang rawan bencana tersebut. Xu et al., (2020) menyebutkan bahwa pemberian keterampilan pemanfaatan teknologi mampu mengurangi resiko gempa bumi pada penduduk desa. 


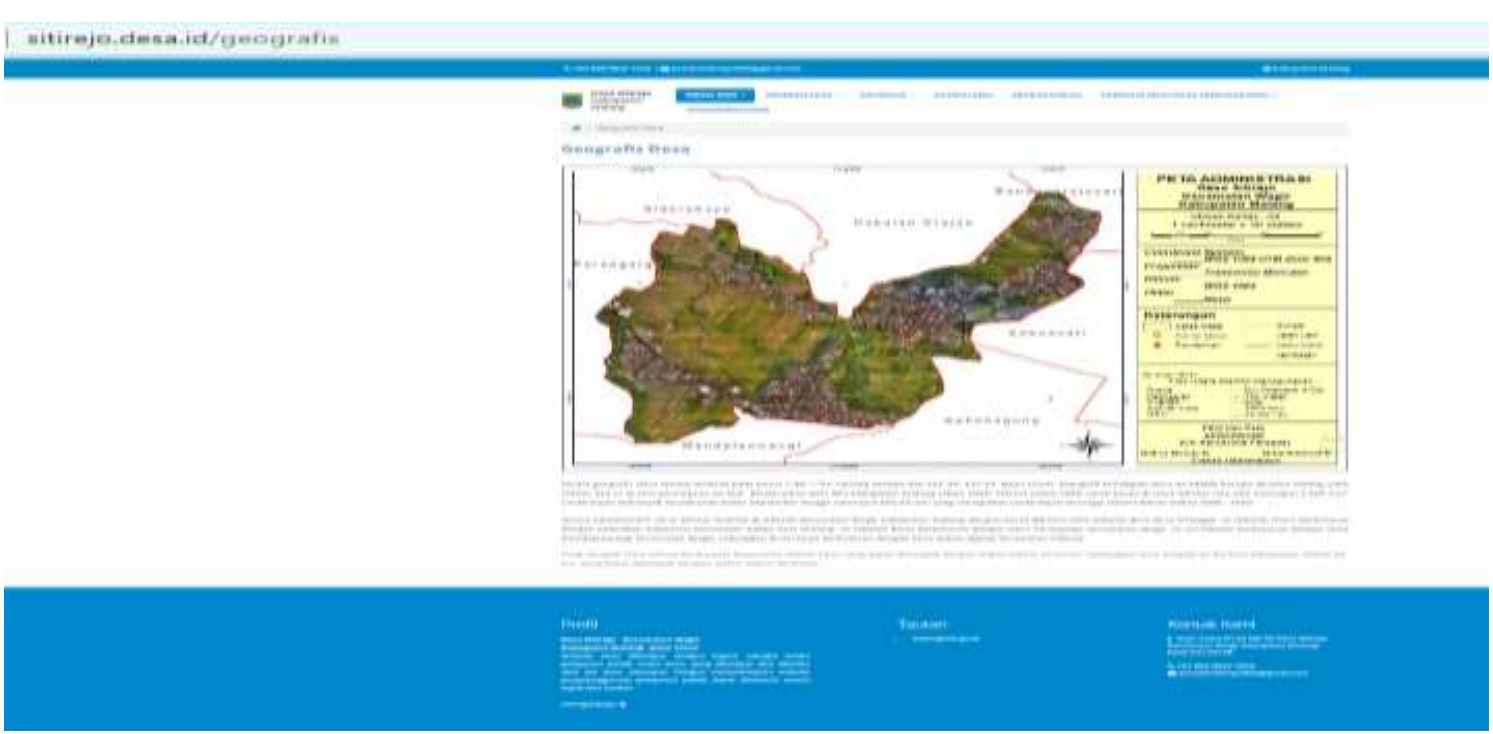

Gambar 7. Pembuatan Konten Geografis Desa

Senada dengan hal di atas, pembuatan konten dan penataan ulang website ini merupakan langkah konkrit untuk menciptakan masyarakat yang melek media dan teknologi. Perubahan dimulai dari perangkat desa dan karang taruna yang nantinya akan ditularkan kepada masyarakat setempat. Hal ini enjadi komitmen bersama pemerintah desa dan karang taruna untuk menjadikan masyarakat desa Sitiarjo menjadi masyarakat melek media dan tekmologi. Sehingga kegiatan ini akan ditularkan kepada seluruh masyarakat desa Sitiarjo.

\section{KESIMPULAN}

Pengabdian kepada masyarakat pada karang taruna dan perangkat desa Sitiarjo ini menekankan pada pelatihan jurnalistik dan literasi media serta pembekalan pengelolaan dan pembuatan konten website desa. Luaran yang dihasilkan mitra memiliki keterampilan jurnalistik dan literasi media. Selain itu, mitra juga memiliki kemandirian dalam pembuatan konten dan pengelolaan website desa. Melalui kegiatan ini desa mampu melakukan promosi wisata desa dengan proyeksi peningkatan perekonomian masyarakat. Mitra juga menjadi peer education untuk mendidik masyarakat setempat agar menjadi masyarakat yang melek media. Adapun rekomendasi dari pengabdian ini adalah tindakan lanjutan pembekalan ketrampilan jurnalistik dan literasi media kepada masyarakat desa Sitiarjo, dan keajegan dalam pengelolaan dan pengisian konten website desa. 


\section{UCAPAN TERIMA KASIH}

Kegiatan ini terlaksana atas kerjasama yang baik antara Perangkat Desa Sitiarjo dan Karang Taruna Sititarjo dengan pengabdi. Kami sampaikan terima kasih atas dukungan partisipasi aktif dalam merancang perubahan dan kemajuan bagi masyarakat.

\section{DAFTAR PUSTAKA}

Anwar, S. A., Sulton, M., K. Zufri, A., Arif, R., Khoirudin, M., Rochman, S. F., Huda, M. D., Cahyani, N. D., Mulyani, D. S., Nurmeisida, T., \& Tasya, R. A. (2020). Website Desa Sebagai Wadah Potensi Ekonomi Mandiri Desa di Era Revolusi Industri 4.0. Jurnal Pembelajaran Pemberdayaan Masyarakat (JP2M), 1(2), 125. https://doi.org/10.33474/jp2m.v1i2.6479

BPS, B. P. S. K. M. (2019). Desa Sitiarjo Kabupaten Malang. https://malangkab.bps.go.id/subject/153/geografi.html\#subjekViewTab3

Farady Marta, R., Hafiar, H., Budi Setiawan, Y., Andriani, F., Lestari, P., Pamungkas, S., Ratri Rahmiaji, L., Alif, M., Yuli Purnama, F., \& Agustina Setyaningsih, L. (2019). Author compliance in following open journal system of communication science in Indonesia. Journal of Physics: Conference Series, 1175(1), 0-10. https://doi.org/10.1088/1742-6596/1175/1/012222

Gui, M., \& Büchi, M. (2021). From use to overuse: Digital inequality in the age of communication abundance. Social Science Computer Review, 39(1), 3-19.

He, X. (2019). Digital entrepreneurship solution to rural poverty: Theory, practice and policy implications. Journal of Developmental Entrepreneurship, 24(1), 1950004.

Herlina, M., \& Husada, S. (2019). Dampak Kejahatan Cyber dan Informasi Hoax Terhadap Kecemasan Remaja di Media Online The Impact of Cyber Crime and Hoax Information on Teenage Anxiety in Online Media. Promedia, 5(2), 89-110.

Hertati, L., Widiyanti, M. Desfitrina, D., Syafarudin, A., \& Safkaur, O. (2020). The Effects of Economic Crisis on Business Finance. International Journal of Economics and Financial Issues, 10(3), 236-244. https://doi.org/https://doi.org/10.32479/ijefi.9928

Kurniawan, Y. I., Chasanah, N., Nofiyati, N., \& Rakhman, A. Z. (2021). Peningkatan Literasi Media dan Pelatihan Pengelolaan Website Sekolah Di SMP Negeri 2 Kalimanah. Jurnal Pengabdian Masyarakat Indonesia, 1(1), 1-6. https://doi.org/10.52436/1.jpmi.3

Lyu, G., Liefner, I., \& Schiller, D. (2019). THE EVOLUTION OF CROSS-BORDER M\&As AND INNOVATION STRATEGIES. Erdkunde, 13(2), 211-224.

Mishori, R., \& Antono, B. (2020). Telehealth, rural America, and the digital divide. The Journal of Ambulatory Care Management, 43(4), 319-322.

Mulyawaty, S., Muljono, P., \& Seminar, K. B. (2016). Efektivitas Website Desa Sebagai Media Penyebaran Informasi Pembangunan Di Desa Malasari Kabupaten Bogor. Scientific Repository IPB, 2(1). 
Nurhayati, S., Musa, S., Boriboon, G., Nuraeni, R., \& Putri, S. (2021). Community Learning Center Efforts to Improve Information Literacy in the Community for Cyber Crime Prevention during a Pandemic. Journal of Nonformal Education, 7(1).

Oktavianoor, R. (2020). Kesenjangan Digital Akibat Kondisi Demografis di Kalangan Masyarakat Rural. Palimpsest: Journal of Information and Library Science, 11(1), 919.

Sani, A., Wiliani, N., Budiyantara, A., \& Nawaningtyas, N. (2020). Pengembangan Model Adopsi Teknologi Informasi terhadap Model Penerimaan Teknologi diantara UMKM. JITK (Jurnal Ilmu Pengetahuan Dan Teknologi Komputer), 5(2), 151-158.

Setiyaningsih, L. A., \& Fahmi, M. H. (2020). Penguatan Community Development Petani Nanas Desa Palaan melalui Digital Marketing. Abdimas: Jurnal Pengabdian Masyarakat Universitas Merdeka Malang, 5(2), 145-151. https://doi.org/10.26905/abdimas.v5i2.4361

Song, Z., Wang, C., \& Bergmann, L. (2020). China's prefectural digital divide: Spatial analysis and multivariate determinants of ICT diffusion. International Journal of Information Management, 52, 102072.

Srivastava, N. K., Krishna, R., Chandran, S., \& Prasad, R. (2019). ICT for Rural and Remote Areas in India. 22nd International Symposium on Wireless Personal Multimedia Communications (WPMC) IEEE, 22, 1-6.

Xu, D., Zhuang, L., Deng, X., Qing, C., \& Yong, Z. (2020). Media exposure, disaster experience, and risk perception of rural households in earthquake-stricken areas: evidence from rural China. International Journal of Environmental Research and Public Health, 17(9), 3246.

Yulida, R., Rosnita, R., Kurnia, D., Andriani, Y., \& ... (2020). Pelatihan Penggunaan Website Untuk Meningkatkan Literasi Media Petani Kelapa Sawit Di Desa Kiap Jaya Kecamatan Bandar Sei Kijang Kabupaten Pelalawan .... Jurnal ABDINUS ..., 3(2), 306-316. https://ojs.unpkediri.ac.id/index.php/PPM/article/view/13850

(C) 2021 by authors. Content on this article is licensed under a Creative Commons Attribution 4.0 International license. (http://creativecommons.org/licenses/by/4.0/). 